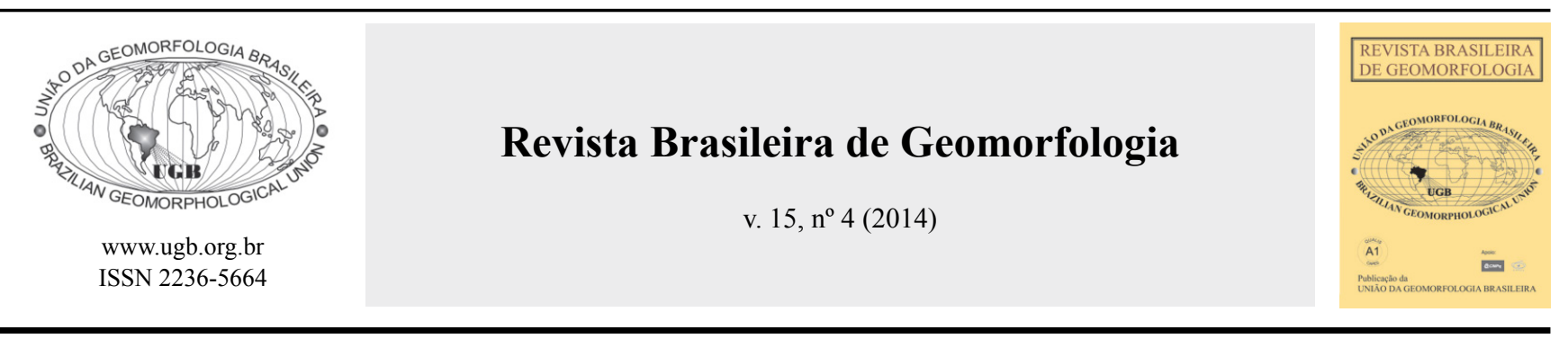

\title{
A DISSECAÇÃO HORIZONTAL COMO PARÂMETRO MORFOMÉTRICO PARA AVALIAÇÃO DO RELEVO: PROPOSTA DE TÉCNICA DIGITAL AUTOMÁTICA
}

\section{HORIZONTAL DISSECTION AS A MORPHOMETRIC PARAMETER TO EVALUATE THE RELIEF: PROPOSAL FOR A DIGITAL AUTOMATIC TECHNIQUE}

\author{
Mateus Vidotti Ferreira \\ Programa de Pós-Graduação em Geociências e Meio Ambiente, Universidade Estadual Paulista \\ Avenida 24 A,1515, Rio Claro/SP, Cep: 13506-900, Brasil \\ E-mail: mateusvidotti@yahoo.com.br \\ Thais Minatel Tinós \\ Programa de Pós-Graduação em Geociências e Meio Ambiente, Universidade Estadual Paulista \\ Avenida 24 A,1515, Rio Claro/SP, Cep: 13506-900, Brasil \\ E-mail:thaistinos@gmail.com \\ Leandro de Godoi Pinton \\ Programa de Pós-Graduação em Geografia, Universidade Estadual Paulista \\ Avenida 24 A,1515, Rio Claro/SP, Cep: 13506-900, Brasil \\ E-mail:lgpgeo@yahoo.com.br
}

Cenira Maria Lupinacci da Cunha

Departamento de Planejamento Territorial e Geoprocessamento, Universidade Estadual Paulista Avenida 24 A,1515, Rio Claro/SP, Cep: 13506-900, Brasil

E-mail:cenira@rc.unesp.br

\section{Informações sobre o Artigo}

Data de Recebimento:

23/05/2014

Data de Aprovação:

$02 / 11 / 2014$

\section{Palavras-chave:}

Análise morfométrica;

Mapeamento automático; Bacia hidrográfica.

\section{Keywords:}

Morphometric analysis;

Automatic mapping; Watershed.

\section{Resumo:}

A morfometria do relevo constitui-se em parâmetro importante para a avaliação da potencialidade morfogenética dos terrenos. Dentre as diversas variáveis passíveis de mensuração, a dissecação horizontal ganha relevância ao permitir avaliar os processos morfogenéticos relacionados com a intensidade da dinâmica fluvial. A obtenção desse tipo de dado, que tradicionalmente envolvia um trabalho moroso, evoluiu bastante com o desenvolvimento de técnicas cartográficas digitais. O objetivo desse artigo é apresentar e discutir uma nova técnica automática desenvolvida em meio digital para a aquisição de dados da dissecação horizontal do relevo. Apresenta-se ainda uma análise comparativa de mapeamentos realizados de forma semiautomática e automática da bacia hidrográfica do Córrego do Cavalheiro (Analândia - SP), na escala de 1:10.000. Os resultados obtidos demonstram que a técnica digital permite maior precisão e demanda menor 
tempo para ser executada. Além disso, a replicabilidade é garantida em razão do uso de algoritmos computacionais, dispensando a subjetividade inerente aos processos analógicos.

\begin{abstract}
:
The morphometry of the relief is an important parameter to evaluate the morphogenetic potential of the land. The horizontal dissection, one of the several variables that can be measured, is relevant, because it allows the evaluation of the morphogenetic processes related to the intensity of fluvial dynamics. The digital mapping techniques have greatly evolved; therefore, it is much easier to obtain this type of data. The objective of this paper is to present and discuss a new automatic technique to obtain horizontal dissection data of the relief. In addition, a comparative analysis of mappings developed through the semi-automatic and automatic techniques in Cavalheiro Stream Basin - Analândia city (SP), on scale of 1:10.000 is presented. The results demonstrate that the digital technique allows greater precision and require less time to be processed. Furthermore, the replicability is guaranteed by the use of computer algorithms, eliminating the inherent subjectivity of analogical processes.
\end{abstract}

\section{Introdução}

A análise morfométrica do relevo visa obter dados quantitativos sobre o terreno, os quais avaliam hierarquicamente a potencialidade de suas características geométricas para o desenvolvimento de processos morfogenéticos. Tricart (1965) considera os dados morfométricos de extrema relevância na avaliação do relevo e os emprega como uma das bases em sua proposta de mapeamento geomorfológico. Tradicionalmente, a obtenção destes dados caracterizava-se por tarefa morosa em virtude da necessidade de análise detalhada de elementos das bases topográficas a fim de mensurar as altitudes do relevo através das curvas de nível, assim como a distribuição da rede de canais de drenagem.

No entanto, a introdução das técnicas digitais na cartografia, viabilizou uma dinamização no processamento e interpretação das variáveis morfométricas. A partir da década de 60 , alguns pesquisadores passaram a publicar suas experiências. Morse (1968) procurou visualizar o comportamento topológico das superfícies topográficas a partir das curvas de nível em ambiente computacional, mas apontou dificuldades para o tratamento satisfatório dos dados expressos em isolinhas. Evans (1972) introduziu pela primeira vez um sistema integrado de geomorfometria, focado principalmente em dados derivados da altitude. Peucker e Douglas (1975) discutiram os problemas de codificação da superfície topográfica nos sistemas computacionais. Mark e Aronson (1984) avaliaram o uso do modelo da geometria fractal para descrever o comportamento estatístico da superfície terrestre, buscando assimilar a complexidade da topografia de forma mais eficiente em ambiente digital. Dikau et al. (1995) adaptaram para o meio digital uma metodologia de classificação do relevo baseada em dados morfométricos derivados de modelos digitais de elevação (MDEs).

Nos últimos anos, um importante progresso foi alcançado na melhoria da precisão altimétrica, com o desenvolvimento de novos algoritmos e softwares para calcular atributos do relevo. Neste contexto, destacam-se os trabalhos de Ehsani e Quiel (2008), Steinke e Sano (2011) e Jasiewicz e Stepinski (2013), que realizaram análises semiautomáticas de dados morfométricos para o reconhecimento de padrões de formas do relevo através de MDEs e, ainda, Ghimire (2014) que identificou e analisou um grupo de variáveis morfométricas para a classificação de bacias hidrográficas de primeira ordem. Além da evolução tecnológica, o desenvolvimento de novas técnicas e metodologias de análise morfométrica do relevo em ambiente computacional foi motivado pelo interesse em superar a subjetividade relativa às interpretações realizadas manualmente.

Florenzano (2008) destaca a importância das cartas morfométricas como possíveis sistemas de mapeamento do relevo que abarcam uma linguagem universal já que se trata de documentos que realizam análises quantitativas do relevo e, portanto, o grau de interpretação dos dados é menor.

Minár e Evans (2008) avigoram tal visão ao proporem que as superfícies sejam classificadas por meio de uma análise geométrica das formas do relevo. Assim, os autores concebem que a homogeneidade morfométrica é reflexo da homogeneidade genética, e as mudanças genéticas estão ligadas com as descontinuidades mor- 
fométricas. Desta forma, a identificação das mudanças morfológicas através de modelos geométricos pautados em bases topográficas inseridas nos Sistemas de Informação Geográfica (SIGs) possibilita a definição de modo matemático das unidades homogêneas de formas do relevo.

Dentre as diversas variáveis passíveis de mensuração para o estabelecimento de uma suposta homogeneidade, a dissecação horizontal, cuja medida corresponde à distância entre as linhas de cumeada e os talvegues, ganha relevância ao permitir avaliar os processos morfogenéticos relacionados com a intensidade da dinâmica fluvial.

Spiridonov (1981) foi o responsável pelo desenvolvimento de uma metodologia para análise desse parâmetro morfométrico. Spiridonov (1981) propôs que a carta de dissecação horizontal fosse elaborada a partir da delimitação das bacias e sub-bacias de drenagem em uma base topográfica. Dentro dos limites de cada bacia, são traçadas as linhas de caimento das encostas e nelas são separadas distintas seções com início nos talvegues. Os pontos equidistantes dos talvegues são unidos mediante curvas, que são equivalentes às isolinhas de distância dos talvegues mais próximos. As faixas geradas representam as classes de dissecação horizontal, sendo coloridas de acordo com a seguinte regra: quanto mais longe do talvegue, menor a dissecação horizontal.

No Brasil, tal metodologia passou por algumas adaptações propostas por Mauro et al. (1991). A primeira etapa foi mantida com a delimitação da bacia e sub-bacias, partindo-se das maiores para as de menor extensão. Na etapa seguinte, houve a implementação de um ábaco que, deslocado entre o talvegue e os divisores de água, auxiliaria na delimitação das classes de dissecação horizontal. As áreas são classificadas de acordo com a distância medida entre as projeções ortogonais do divisor de água e do fundo de vale em um plano horizontal. O trabalho de Mauro et al. (1991) se tornou a base para muitos estudos produzidos no país. Dentre esses estudos, destaca-se o desenvolvido por Zacharias (2001), que propôs uma semiautomatização da metodologia em ambiente digital por meio de uma plataforma Computer-aided design (CAD). A autora alcançou um ganho de operacionalidade, visto que as informações armazenadas em meio digital permitiram aos usuários realizar alterações dos dados em qualquer etapa do trabalho. Entretanto, a metodologia continua demandando considerável tempo e obrigatoriamente apresenta imprecisões relacionada aos procedimentos desenvolvidos manualmente. Desde então, não houve avanços metodológicos nesta área.

O objetivo deste artigo é apresentar e discutir uma nova técnica automática desenvolvida em meio digital para a obtenção de dados da dissecação horizontal do relevo. Para sua validação foi realizada uma análise comparativa com o mapeamento elaborado com base na proposta metodológica semiautomática de Zacharias (2001) na bacia hidrográfica do Córrego do Cavalheiro - Analândia (SP), na escala de 1:10.000.

\section{2. Área de Estudo}

A bacia hidrográfica do Córrego do Cavalheiro localiza-se entre as coordenadas geográficas de

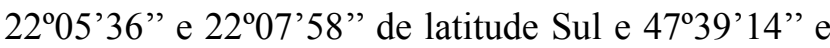
47 41 '28" de longitude Oeste, possuindo uma área de $9,9 \mathrm{~km}^{2}$ (Figura 1). Esta bacia situa-se na maior unidade geológica do Estado de São Paulo - a bacia sedimentar do Paraná, sendo disposta na transição entre as Cuestas Areníticas-Basálticas e a Depressão Periférica Paulista.

De acordo com Ab'Sáber (1969), a gênese de ambos os compartimentos está relacionada com o processo de circundesnudação, de idade pós-cretácea, ocorrido nas margens da bacia sedimentar do Paraná, na qual os "[...] fenômenos de desnudação marginal se processaram de um modo mais generalizado e normal, vindo a corresponder, em conjunto, a um sistema típico de circundesnudação, dos mais extensos de que se tem notícia no relevo terrestre" (Ab'Sáber, 1949, p. 9). No que tange a morfogênese do relevo de cuestas da bacia do Paraná, destaca-se ainda a existência de estudos que indicam que essa pode estar atrelada a influência da morfotectônica (Penteado, 1968, 1974; Facincani, 2000).

Independentemente da abordagem adotada, a morfogênese responsável por ambos os compartimentos geomorfológicos desenvolve-se sobre litologias cuja deposição ocorreu desde o período Mesozóico ao Cenozóico. De acordo com São Paulo (1984), datadas do Mesozóico, encontram-se as formações pertencentes ao Grupo São Bento - Pirambóia, Botucatu e Serra Geral - e, ainda, a formação Itaqueri. É necessário destacar que não há um consenso para a datação da formação Itaqueri, pois essa já foi considerada inicialmente como série basal do Grupo Bauru e, atualmente, alguns autores indicam que sua formação pode ser posterior ao referido grupo (Melo, 1995). No que se refere às litologias 


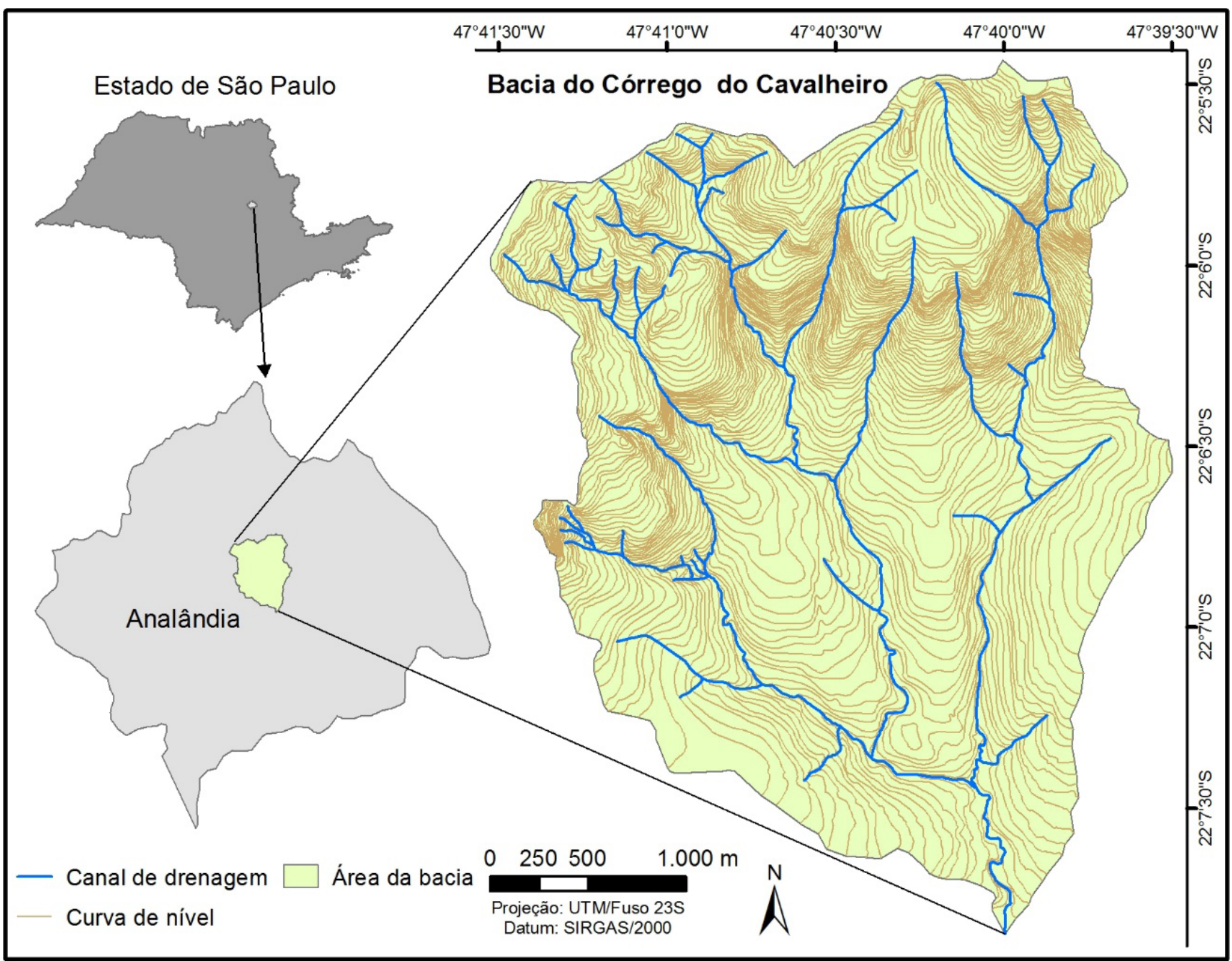

Figura 1 - Localização da Bacia do Córrego do Cavalheiro.

datadas do Cenozóico, encontra-se apenas a formação Santa Rita do Passa Quatro (SÃO PAULO, 1984).

Assim, a bacia do Córrego do Cavalheiro apresenta feições geomorfológicas diversas, tanto em função da litologia como da evolução morfogenética do setor cuestiforme. Essa diversidade de feições foi objeto do mapeamento da dissecação horizontal por meio de duas técnicas diferentes, a seguir apresentadas.

\section{Procedimentos para o Mapeamento da Dissecação Horizontal}

A base cartográfica utilizada nesta pesquisa constitui-se de cartas topográficas executadas pela Secretaria de Economia e Planejamento do Governo do Estado de São Paulo, Coordenadoria de Ação Regional - Divisão de Geografia - na escala de 1:10.000. A bacia do Córrego do Cavalheiro compreende as folhas Analândia I (SF23-Y-A-I-2-NO-F), Analândia II (SF-23-Y-A-I-2-SO-B) e Serra da Estrela (SF-23-Y-A-I-2-NO-E), datadas do ano de 1979. A bacia do córrego do Cavalheiro e suas sub-bacias foram delimitadas por meio da interpretação dessas cartas topográficas.

O procedimento automático proposto neste artigo é baseado em uma ferramenta específica desenvolvida no interior do software ArcGIS 10.2.1 (ESRI, 2013). A ferramenta encontra-se disponível para download no link http://1drv.ms/S7ZdgT. Esta ferramenta tem por objetivo gerar polígonos que representem a dissecação horizontal a partir de linhas que conectem um ponto do canal de drenagem a um ponto mais próximo da borda da sub-bacia, com um ângulo aproximado de $90^{\circ} \mathrm{em}$ relação ao canal de drenagem. A ferramenta representa uma automatização da proposta de Spiridonov (1981) 
e da adaptação de Mauro et al. (1991). Sua interface pode ser observada na figura 2.

Os dados de entrada na ferramenta são os polígonos das sub-bacias e seus respectivos canais de drenagem em formato de linha. É importante que as linhas de drenagem estejam com os pontos finais posicionados no exutório da bacia. Em seguida, deve-se informar três variáveis: um parâmetro de segmentação dos canais de drenagem, ou seja, um valor para a divisão do canal de drenagem em trechos equidistantes; um parâmetro de agrupamento dos canais de drenagem; e os limiares superiores das classes de dissecação desejada.

O estabelecimento do parâmetro de segmentação se dá a partir da escala de trabalho. De acordo com o IBGE (1999), o menor comprimento gráfico que se pode representar em um desenho é $1 / 5$ de milímetro ou 0,2 $\mathrm{mm}$, pois esse seria o menor valor pontual que a vista humana pode distinguir. Em termos lineares, para um mapa na escala 1:10.000, o valor estabelecido para o erro gráfico é de 2 metros, ou seja, esse é o menor valor linear distinto nesta escala. Assim, o parâmetro de segmentação foi definido como 2 metros.
O parâmetro de agrupamento dos canais de drenagem é uma variável diretamente relacionada a sinuosidade do canal e ao parâmetro de segmentação. Em áreas com canais muito sinuosos a ferramenta tende a apresentar um resultado menos satisfatório, pois a diversidade de direções dos segmentos dos canais de drenagem gera problemas na criação das linhas de dissecação horizontal. Aconselha-se que para cada área sejam testados diferentes valores do parâmetro de agrupamento para se atingir melhores resultados. Neste artigo, definiu-se de maneira empírica um valor do parâmetro de agrupamento igual a 60 (segmentos).

As classes de dissecação também devem ser estabelecidas conforme a escala de trabalho. Assim, para a primeira classe, o valor estabelecido foi menor ou igual a $10 \mathrm{~m}$, representando 5 vezes o menor valor linear distinto nesta escala $(2 \mathrm{~m})$. Seguindo-se a recomendação de Spiridonov (1981), o valor das classes seguintes foi atribuído com base no dobro do limite da classe anterior, até atingir o máximo de distância ainda representativa para a área. As classes de dissecação e suas respectivas cores são apresentadas na tabela 1 .

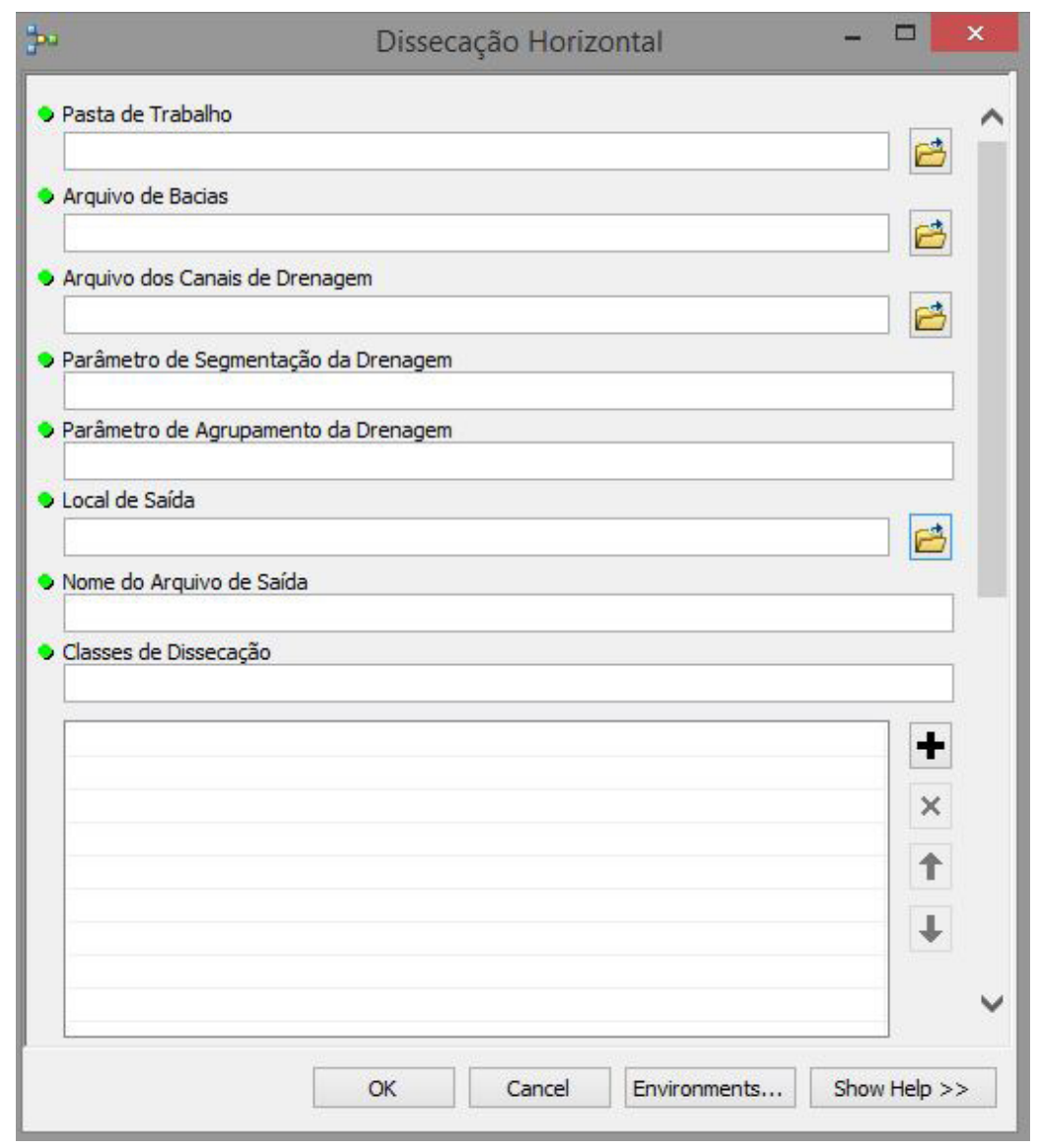

Figura 2 - Interface da ferramenta criada para a técnica digital automática de dissecação horizontal. 
Tabela 1: Classes de dissecação horizontal.

\begin{tabular}{|c|c|c|c|}
\hline $\begin{array}{c}\text { Intervalo } \\
\text { (em metros) }\end{array}$ & ID da classe & $\begin{array}{c}\text { Classes de } \\
\text { dissecação }\end{array}$ & $\begin{array}{c}\text { Cores da } \\
\text { legenda }\end{array}$ \\
\hline$<10$ & 1 & Classe 1 & \\
$10-20$ & 2 & Classe 2 & \\
$20-40$ & 3 & Classe 3 & \\
$40-80$ & 4 & Classe 4 & \\
$80-160$ & 5 & Classe 5 & \\
$160-320$ & 6 & Classe 6 & \\
$\geq 320$ & 7 & Classe 7 & \\
\hline
\end{tabular}

Abaixo são descritos os passos realizados pela ferramenta para a geração do mapa de dissecação horizontal.

Passo 1: Verifica-se a existência de algum ponto de nascente no interior da bacia. Caso haja, um processamento específico será realizado para esse ponto (Passo 10). A verificação é realizada automaticamente por meio do canal de drenagem fornecido.

Passo 2: Divide-se a linha de drenagem em segmentos de mesma extensão de acordo com o parâmetro de segmentação. Na sequência, é criado um ponto no centro de cada segmento. Esse ponto será o ponto inicial das linhas candidatas a linhas de dissecação horizontal. A figura $3 \mathrm{~A}$ mostra os pontos centrais criados sobre o canal de drenagem. Neste exemplo, a ferramenta criou 157 pontos com equidistância de 2 metros para uma escala de 1:10.000.

Passo 3: Calcula-se a direção de cada agrupamento de 60 segmentos de drenagem. Optou-se por utilizar a direção de um grupo de segmentos para minimizar a influência das grandes variações que podem ocorrer quando se considera apenas um pequeno segmento. A direção do agrupamento de segmentos utilizada nesta ferramenta é um ângulo que varia de -90 graus a +90 graus. Colocada em um plano cartesiano, essa variação equivale ao primeiro e ao quarto quadrantes. A direção então é associada aos respectivos pontos pertencentes a cada agrupamento. Esse parâmetro será essencial para determinar a linha de dissecação horizontal.

Passo 4: Criam-se pontos equidistantes sobre a borda da bacia, os quais serão candidatos a pontos finais das linhas de dissecação horizontal. A distância entre esses pontos foi definida empiricamente como sendo o tamanho do segmento de drenagem dividido por 4 .
Desta forma, quanto menor o tamanho do segmento, maior será o número de pontos na borda da bacia. No exemplo apresentado na figura $3 \mathrm{~B}$, observam-se os pontos gerados sobre a borda da bacia. Neste caso, como a distância definida para o segmento de drenagem foi de 2 metros, a distância entre os pontos da bacia é de aproximadamente 0,5 metro.

Passo 5: Inicia-se o processamento individual de cada ponto do canal de drenagem para encontrar a melhor linha de dissecação horizontal para o lado direito e para o lado esquerdo do canal. Os pontos são processados das extremidades da linha de drenagem para o centro da mesma de forma alternada, ou seja, inicia-se com o ponto mais próximo da jusante, em seguida processa-se o ponto mais próximo da montante e depois o segundo ponto mais próximo da jusante e assim sucessivamente.

Os procedimentos para escolha das linhas de dissecação serão descritos nos passos seguintes.

Passo 6: Tomando como referência o ponto destacado em preto na figura $3 \mathrm{C}$, cria-se um arquivo com as linhas candidatas a linha de dissecação horizontal. Essas linhas ligam o ponto selecionado a todos os pontos da bacia, como pode ser visualizado na figura 3C. Para cada uma das linhas é calculado o azimute geográfico.

Passo 7: Utilizando a relação entre o azimute de cada linha candidata e a direção do segmento de drenagem calculado anteriormente, encontram-se as linhas que estão próximas a perpendicular do segmento de drenagem. Foi definido um intervalo de busca para as linhas com um ângulo de mais ou menos 5 graus a partir da perpendicular do agrupamento de segmentos de drenagem a qual pertence o ponto. As linhas selecionadas por meio desse critério são apresentadas na figura 3D. 


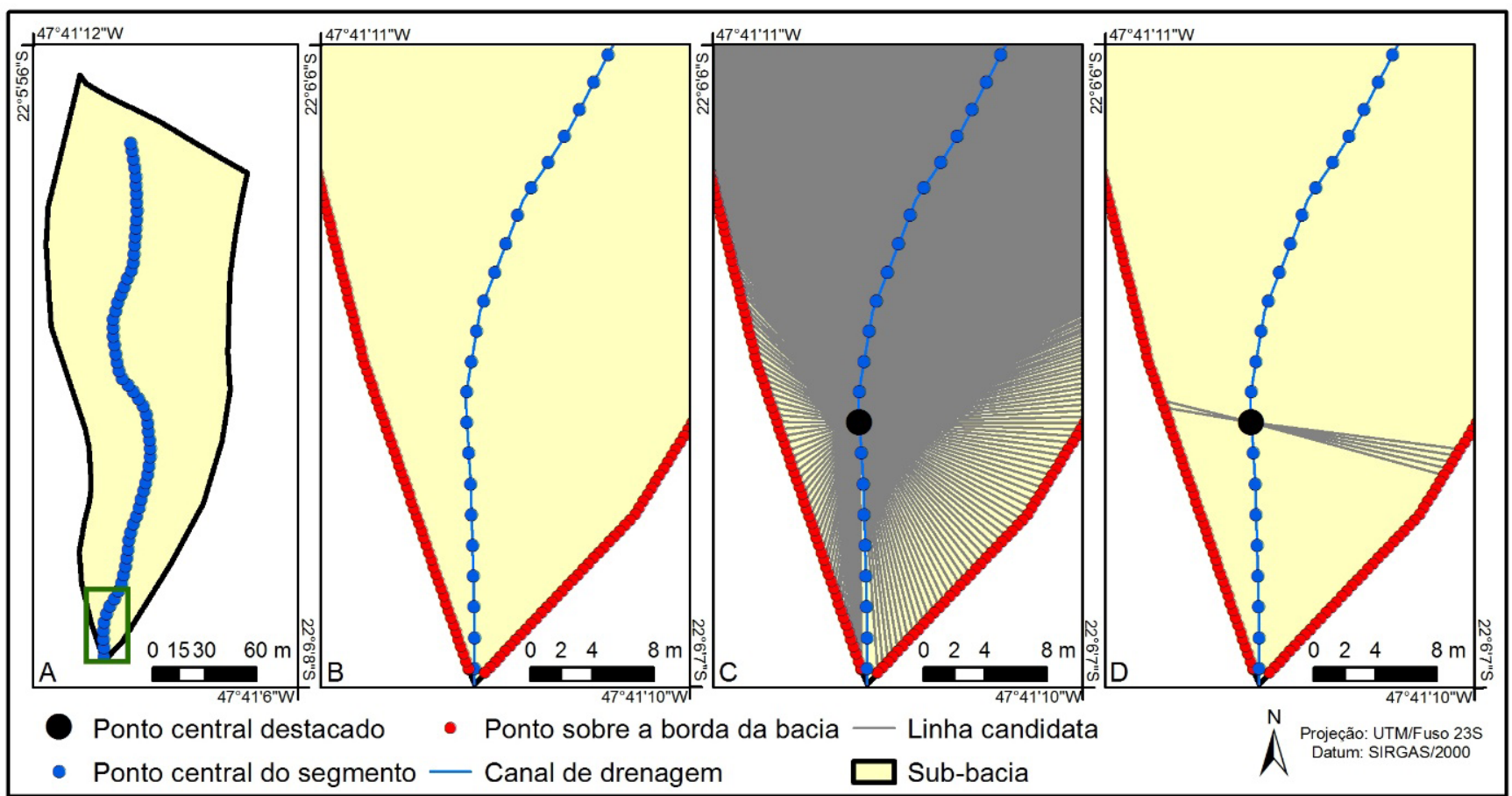

Figura 3 - Dissecação horizontal automática: A - Pontos centrais criados sobre o segmento de drenagem; B - Detalhe dos pontos criados sobre a borda da bacia; $C$ - Linhas candidatas a linha de dissecação horizontal do ponto em destaque; D-Linhas candidatas selecionadas pelo critério do ângulo.

Passo 8: Aplicam-se então os seguintes procedimentos para encontrar a melhor linha de dissecação da direita e da esquerda do canal de drenagem:

- Utilizando a mesma relação entre direção do segmento de drenagem e o azimute das linhas candidatas, encontram-se as linhas que estão à esquerda do segmento de drenagem;

- Dentre as linhas da esquerda selecionadas, excluem-se aquelas que

- cruzam o canal de drenagem;

- cruzam a borda da bacia;

- interceptam linhas de dissecação horizontal de outros pontos;

- Por fim, seleciona-se a linha que tenha o menor comprimento entre o canal de drenagem e a borda da bacia;

- Repetem-se as últimas três etapas para encontrar a melhor linha da direita.

Passo 9: Repetem-se então os passos 7 e 8 para cada um dos pontos do canal de drenagem restantes.

Se houver uma nascente no interior da bacia, essa será processada no passo seguinte.
Passo 10: Para o processamento da nascente realizam-se as seguintes etapas:

- Aplica-se o mesmo procedimento descrito no passo 6 para construção das linhas. No entanto, utilizam-se os pontos sobre a borda da bacia com espaçamento equivalente ao parâmetro de segmentação do canal de drenagem utilizado;

- Não é aplicado o procedimento do passo $7 \mathrm{de}$ restrição angular da linha.

- Excluem-se as linhas que

- cruzam a borda bacia;

- cruzam o canal de drenagem;

- interceptam linhas de dissecação horizontal de outros pontos;

A figura 4A apresenta as linhas selecionadas após a aplicação dos passos anteriores.

Passo 11: Os polígonos de dissecação são criados utilizando as linhas de dissecação horizontal, a linha da drenagem e o polígono da bacia.

Passo 12: Gera-se um mapa de distância euclidiana a partir do segmento de drenagem. Esse mapa será utilizado para o cálculo da distância máxima dentro de 
cada um dos polígonos gerados no passo 11. O mapa de distância do canal de drenagem pode ser visualizado na figura 4B.

Passo 13: Por meio de uma análise zonal, utilizando os polígonos de dissecação e o mapa de distâncias, calcula-se para cada polígono sua distância máxima do canal de drenagem.
Passo 14: Baseando-se na distância máxima, cada polígono é então classificado de acordo com as classes previamente definidas (Tabela 1). Os polígonos contíguos que pertençam a mesma classe são agrupados. O resultado deste processamento são os polígonos de dissecação horizontal. A figura 4C ilustra a representação espacial deste atributo.
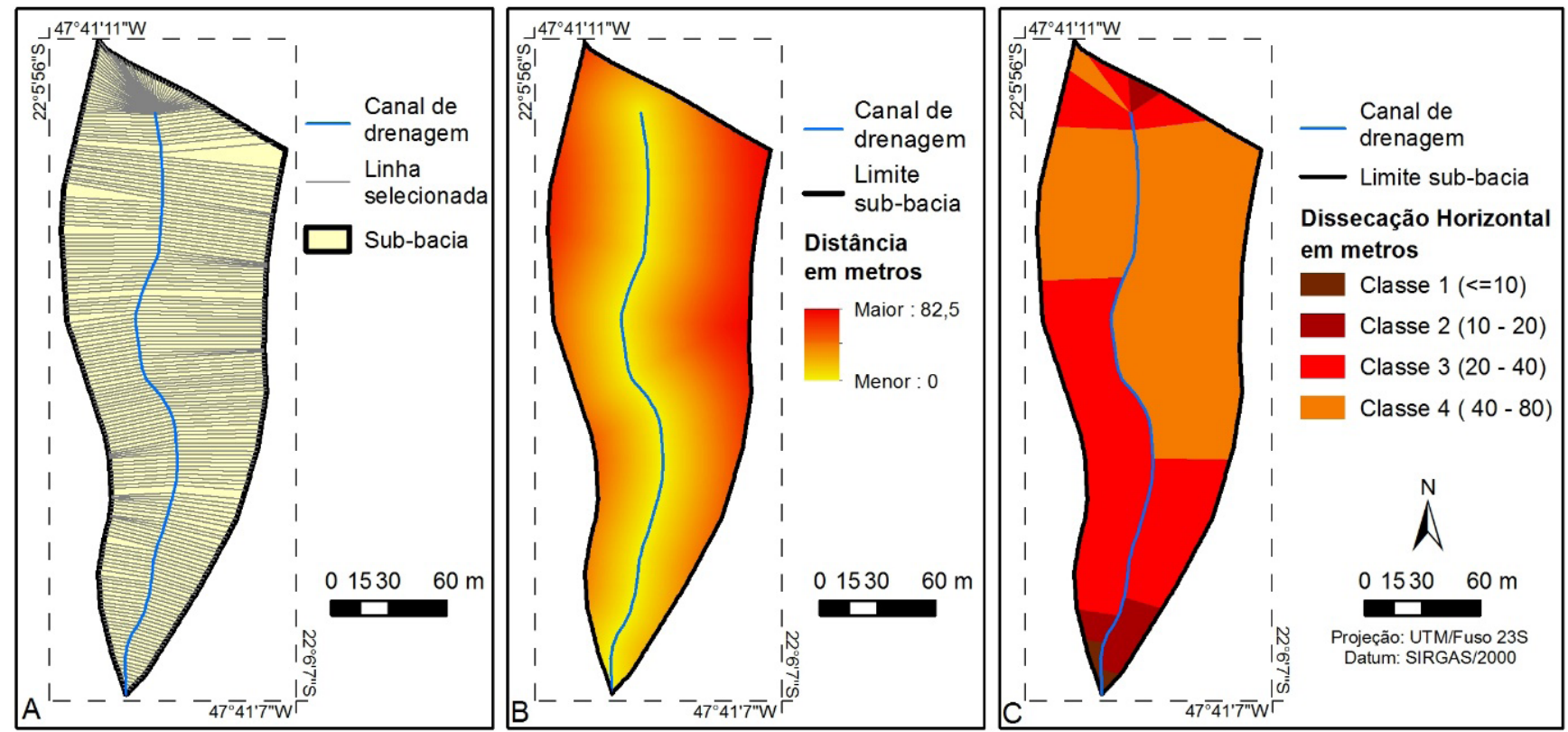

Figura 4 - Dissecação horizontal automática: A - Linhas selecionadas para os lados direito e esquerdo do canal de drenagem; B - Mapa da distância euclidiana do canal de drenagem; $C$ - Mapa de dissecação horizontal da sub-bacia.

Após o mapa de dissecação horizontal ser produzido utilizando a ferramenta descrita, este foi comparado com um mapa de dissecação horizontal gerado a partir da técnica semiautomática proposta por Zacharias (2001). Este produto foi selecionado para validação por três motivos: 1. emprega o mesmo referencial teórico para o cálculo da dissecação horizontal (Spiridonov, 1981; Mauro et al., 1991), o que garante uma comparabilidade; 2 . é desenvolvido também em meio digital, o que facilita a análise e diminui possíveis erros de digitalização; 3 . é uma técnica muito utilizada para o estudo da dissecação horizontal no Brasil. A figura 5 ilustra a construção da carta de dissecação horizontal através da técnica semiautomática de Zacharias (2001).

A partir da comparação dos mapas resultantes das duas técnicas, foram quantificadas as áreas de concordância e discordância das classes de dissecação horizontal geradas. Dentre as áreas identificadas como divergentes, avaliou-se o grau de discordância por meio da Equação 1.

$$
\text { Grau de discordância }=\left|\mathrm{ID}_{\text {auto }}-\mathrm{ID}_{\text {Semi }}\right|
$$

Em que: $\mathrm{ID}_{\text {auto }}$ é o ID da classe gerada pela técnica automática e $\mathrm{ID}_{\text {semi }}$ é o ID da classe gerada pela técnica semiautomática.

\section{Resultados e Discussões}

A partir da figura 6 é possível observar os resultados obtidos através da técnica digital automática de dissecação horizontal (Figura 6A) e comparar com o mapa elaborado por meio da técnica semiautomática proposta por Zacharias (2001) para a área da bacia do Córrego do Cavalheiro (Figura 6B). A tabela 2 apresenta a concordância entre as duas técnicas por classe de dissecação horizontal. 


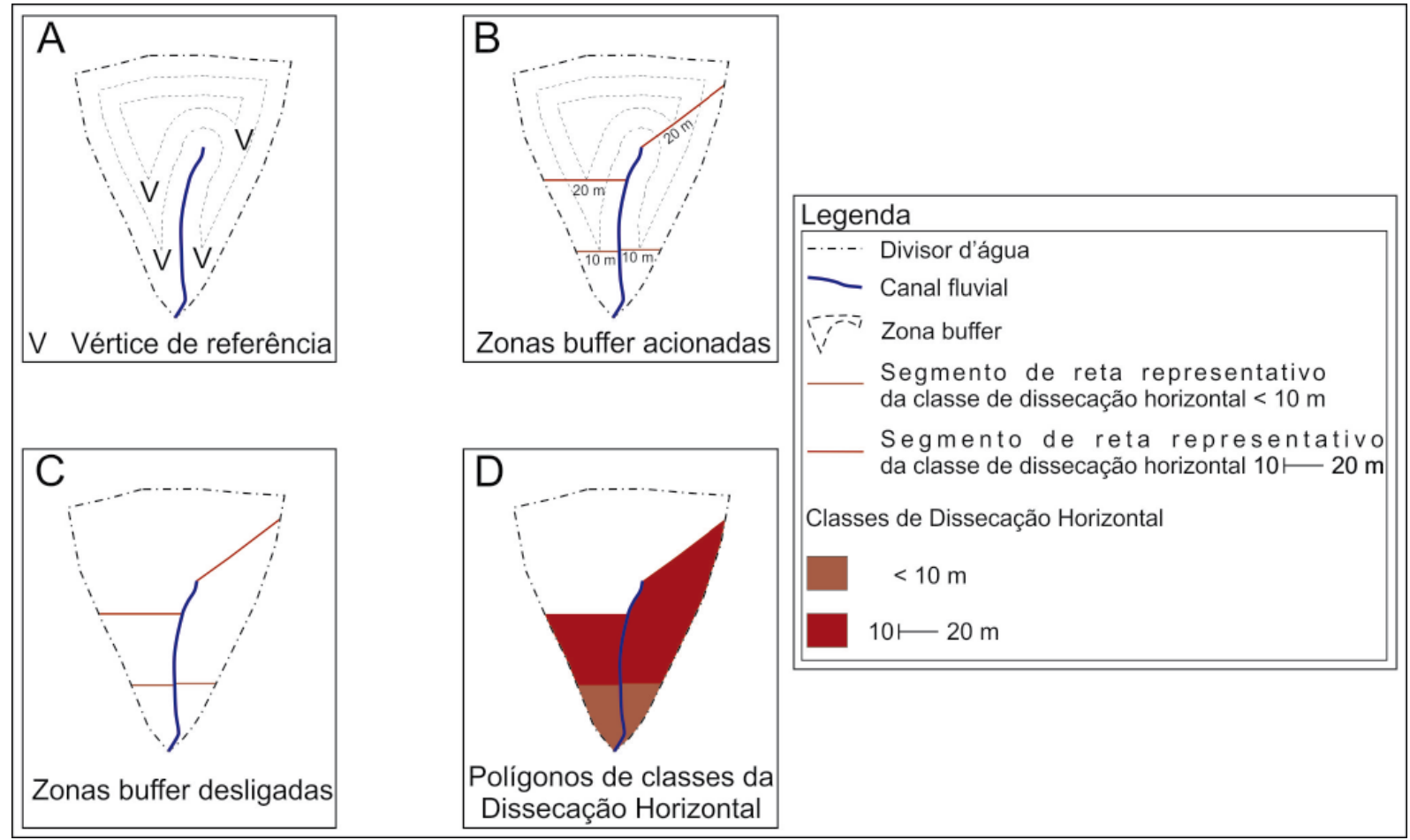

Figura 5 - Etapas para a construção da carta de dissecação horizontal através da técnica semiautomática de Zacharias (2001). Fonte: Adaptado de Zacharias (2001).

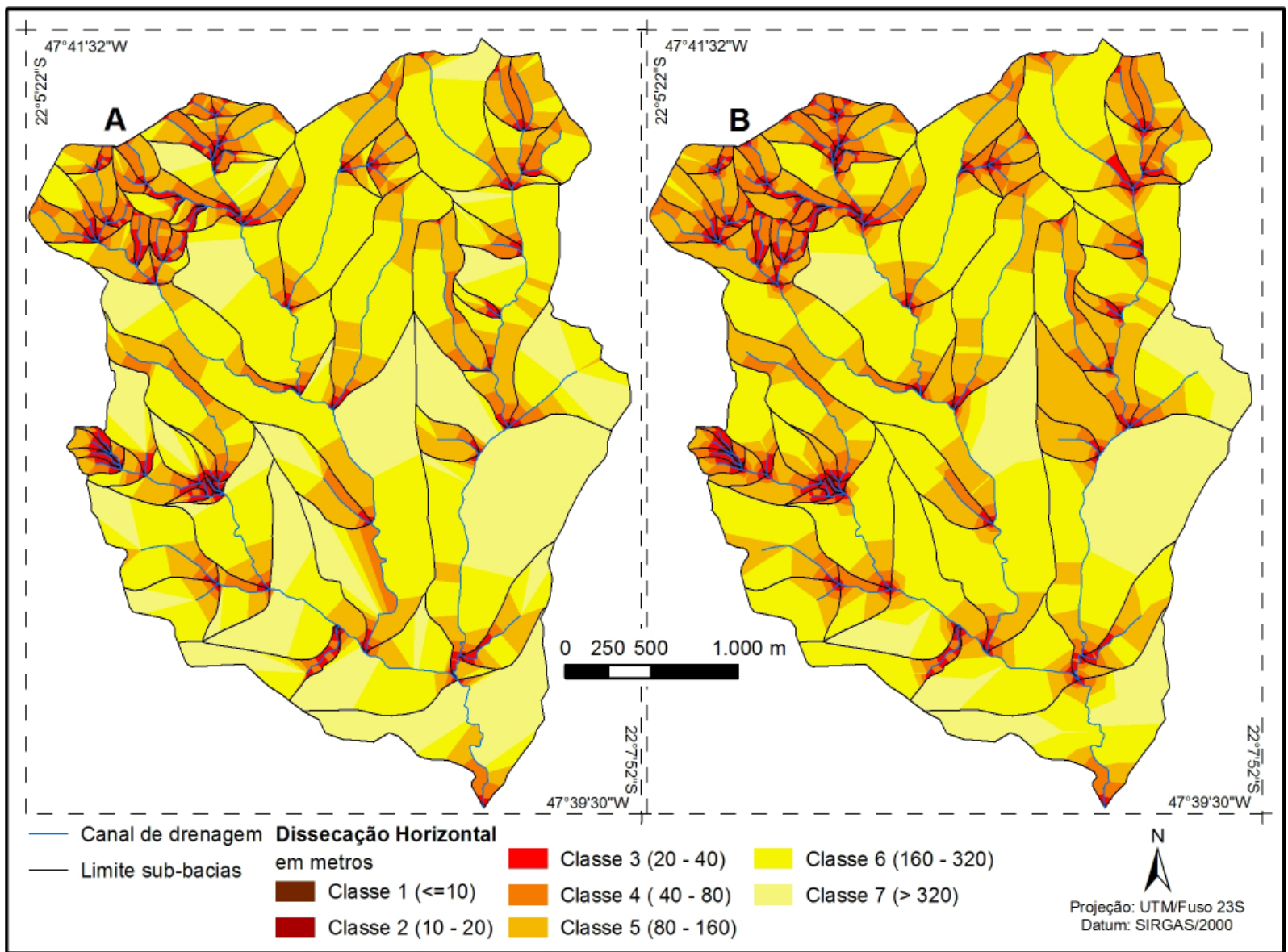

Figura 6 - Mapa de dissecação horizontal: A - técnica automática; $B$ - técnica semiautomática. 
Tabela 2: Concordância por classe de dissecação horizontal.

\begin{tabular}{|c|c|c|}
\hline Classes de dissecação & $\begin{array}{c}\text { Área total em } \mathrm{m}^{2} \\
\text { (automático) }\end{array}$ & $\begin{array}{c}\text { Concordância com } \\
\text { semiautomático (\%) }\end{array}$ \\
\hline Classe 1 & 15473 & 92,63 \\
Classe 2 & 55135 & 90,93 \\
Classe 3 & 229036 & 92,11 \\
Classe 4 & 812890 & 89,24 \\
Classe 5 & 1976603 & 85,14 \\
Classe 6 & 4077288 & 80,05 \\
Classe 7 & 2740552 & 49,00 \\
Total & 9906977 & 73,59 \\
\hline
\end{tabular}

A partir de uma análise quantitativa, observa-se que $73,59 \%$ da área da bacia foi classificada com as mesmas classes de dissecação horizontal em ambas as técnicas testadas. Esse elevado valor de concordância atesta que a ferramenta desenvolvida reproduziu satis- fatoriamente a técnica semiautomática. A figura 7 ilustra a distribuição das áreas de concordância e discordância resultantes da comparação das duas técnicas e a tabela 3 apresenta a porcentagem de área correspondente a cada grau de discordância.

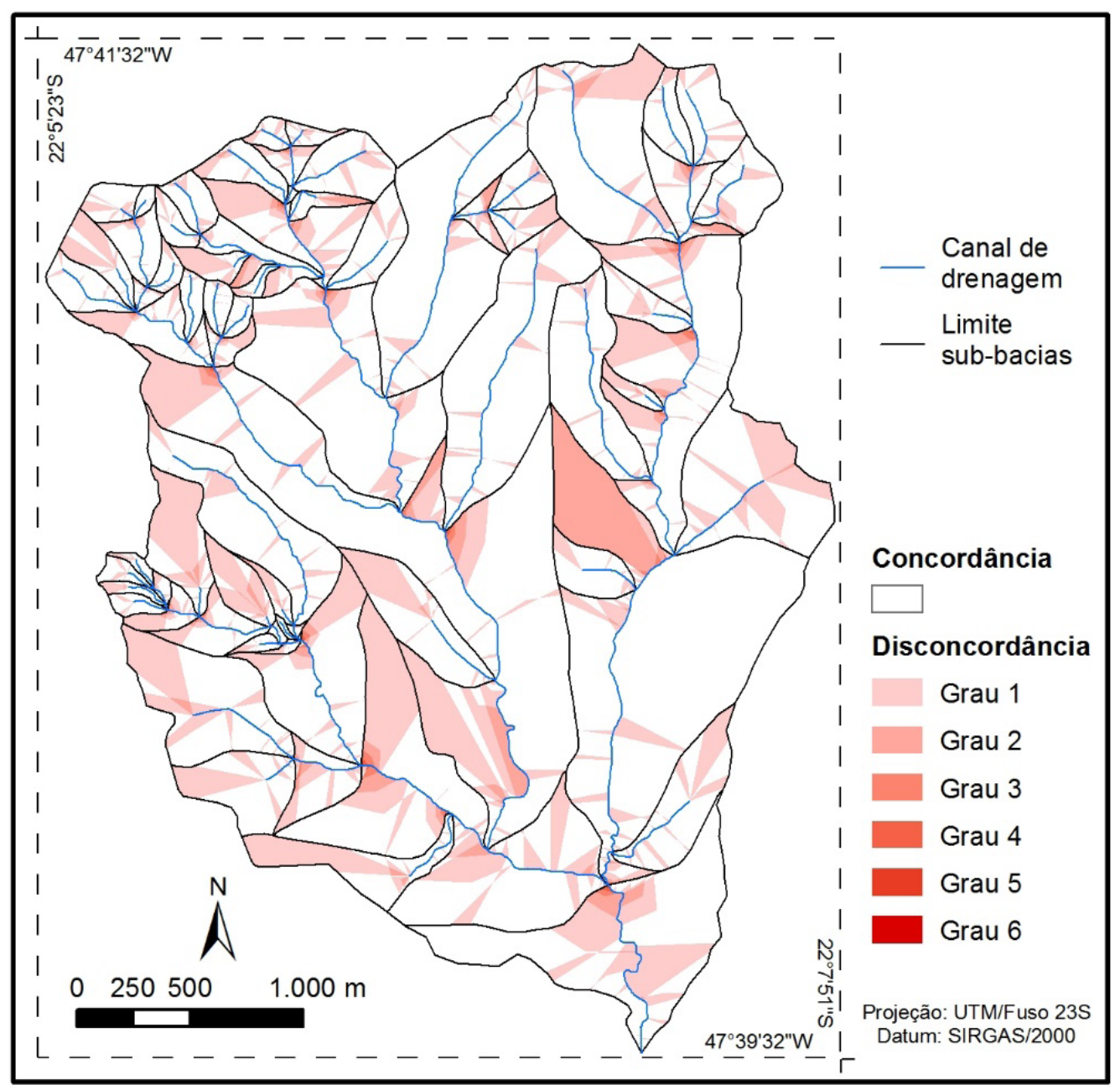

Figura 7 - Distribuição das áreas de concordância e discordância resultantes da comparação das duas técnicas. 
Tabela 3: Porcentagem de área correspondente a cada grau de discordância.

\begin{tabular}{|c|c|c|}
\hline Grau de discordância & $\begin{array}{c}\text { Área em relação } \\
\text { ao total da área } \\
\text { discordante }(\%)\end{array}$ & $\begin{array}{c}\text { Área em relação ao } \\
\text { total da área da bacia } \\
(\%)\end{array}$ \\
\hline Grau 1 & 85,52 & 22,59 \\
Grau 2 & 13,28 & 3,51 \\
Grau 3 & 0,94 & 0,25 \\
Grau 4 & 0,21 & 0,05 \\
Grau 5 & 0,04 & 0,01 \\
Grau 6 & 0,01 & $<0,01$ \\
Total & 100 & 26,41 \\
\hline
\end{tabular}

Os 26,41\% de áreas discordantes nos mapas ocorreram devido a três principais fatores: 1 . a técnica digital automática possibilita uma maior precisão na medição dos ângulos e distâncias estipulados pela metodologia; 2. ambas as técnicas apresentam limitações quanto as áreas de canais sinuosos e optam por diferentes soluções; 3. ambas as técnicas apresentam procedimentos diferentes para as áreas a montante das nascentes e para as áreas de confluências.

Como mostra a tabela 3, as discordâncias de Grau 1 e 2 equivalem a $98,80 \%$ do total das áreas discordantes e correspondem a divergências de até duas classes. Esses graus de discordância estão associados principalmente ao fator 1 descrito anteriormente, ou seja, a maior precisão na medição dos ângulos e distâncias, e também ao fator 3 , relativo ao procedimento adotado para as áreas de nascentes.

Os Graus de discordância 3, 4, 5 e 6 equivalem a $1,2 \%$ do total das áreas discordantes e correspondem a divergências de até seis classes. As áreas identificadas com esses graus de discordância estão relacionadas essencialmente ao fator 2, relativo as soluções encontradas para o tratamento de áreas com canais sinuosos e também ao procedimento adotado para áreas de confluências citado no fator 3 .

A seguir discutem-se mais profundamente os avanços e limitações encontrados no desenvolvimento da técnica digital automática.

\subsection{Definição das classes de dissecação horizontal}

Uma questão problemática da proposta semiautomática, embutida no mapeamento convencional, refere- -se à definição das classes de dissecação, as quais devem ser estabelecidas a priori. É necessário realizar uma análise detalhada do espaçamento entre rios e linhas de cumeada para que os limites das classes efetivamente representem a variedade da dimensão dos interflúvios. Considerando que os limites das classes inferiores seguem a orientação de Spiridonov (1981) sobre o menor intervalo possível de ser mapeado, um problema comum pode ocorrer com as classes superiores. A partir do menor intervalo definido, os valores são dobrados a fim de se estabelecer as demais classes. Contudo, o número de classes a ser mapeado e o limite superior da última classe é fixado de acordo com a distância máxima identificada entre o rio e divisor de água na análise da base cartográfica. Desta forma, se tal análise não for rigorosa, duas situações podem ocorrer: a. intervalos de classe pouco representativos, isto é, classes que ocorrem em um número reduzido de setores do mapa; b. generalização dos setores menos dissecados, ou seja, aqueles com maior distância entre a linha de cumeada e o talvegue em função de um número reduzido de classes.

O procedimento automático possibilita a realização de testes que ajudam a solucionar tais situações, visto que a ferramenta digital possibilita experimentar inúmeros intervalos de classe com facilidade e rapidez.

\subsection{Precisão na classificação da dissecação horizontal}

A técnica semiautomática exige do usuário o controle de muitas etapas e assim se encontra sujeita a equívocos, derivados de pequenos detalhes que podem passar despercebidos na medição dos ângulos e distâncias estipulados pela metodologia. 
Neste contexto, ressaltam-se as limitações identificadas nos trechos caracterizados por elevada sinuosidade dos cursos fluviais e nas confluências com ângulos abertos. Nestas situações, a delimitação das classes de dissecação horizontal segundo a proposta de Spiridonov (1981) se encontra comprometida, pois se torna impossível digitalizar o segmento de reta com um ângulo aproximado de $90^{\circ}$ entre os divisores d'água e os talvegues. Assim, na técnica semiautomática recomenda-se o uso de acutângulos (ângulos inferiores a $90^{\circ}$ ) no traçado de tais segmentos, atentando-se na manutenção das distâncias reais de cada classe ao longo do processo de digitalização. A figura 8 mostra as referidas situações e a adaptação realizada para conter as distorções nas distâncias equivalentes às classes de dissecação horizontal.

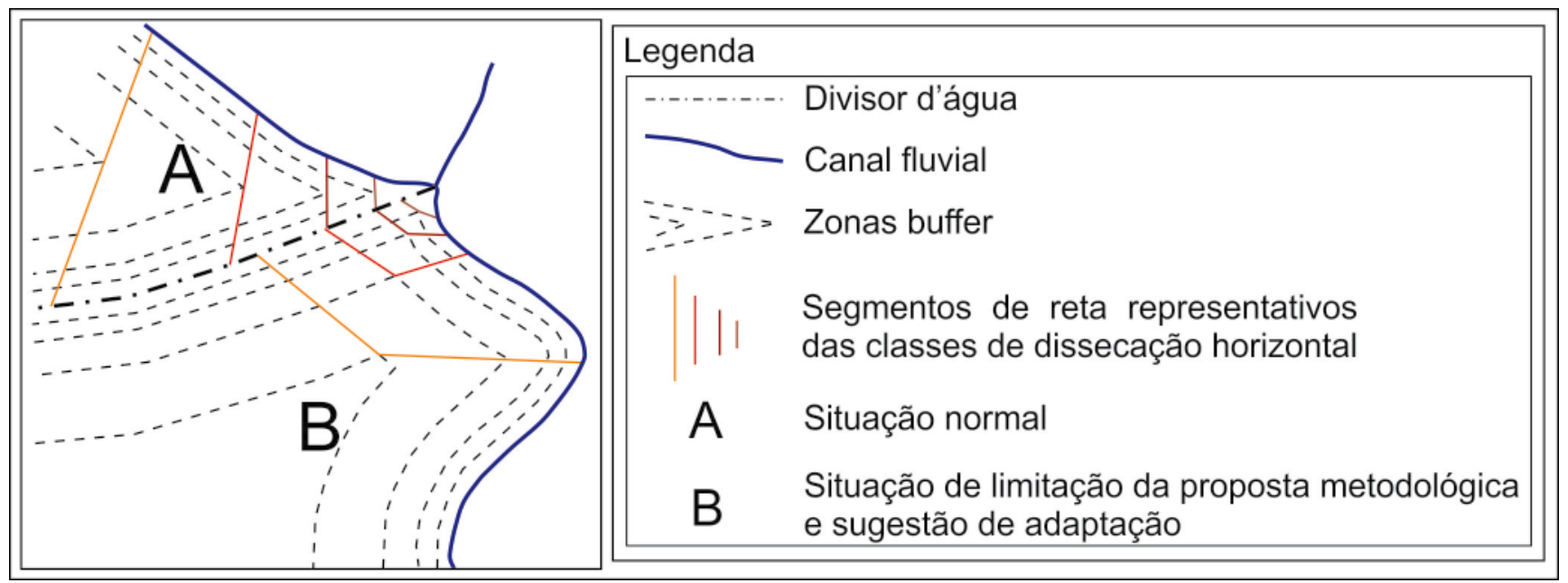

Figura 8 - Situações de limitação da técnica semiautomática proposta por Zacharias (2001) e a medida adotada para evitar as distorções no estabelecimento das classes de dissecação horizontal.

A técnica digital automática apresenta uma solução alternativa para tais limitações. Para os canais sinuosos, o parâmetro de agrupamento dos segmentos de drenagem é determinante para o traçado das linhas de dissecação com maior precisão. A figura 9 apresenta três resultados para um trecho sinuoso do canal de drenagem. A figura 9A é resultado da aplicação da técnica semiautomática, em que é possível visualizar as classes geradas a partir da adaptação mostrada na figura 8. As figuras 9B e 9C são resultados da aplicação da técnica automática com parâmetros de agrupamento distintos, equivalentes a 60 e 120 segmentos respectivamente. A análise das figuras 9B e 9C possibilita afirmar que o parâmetro de agrupamento 120 foi o mais adequado para esta situação específica, apesar do parâmetro de agrupamento igual a 60 ter tido um desempenho satisfatório para todo o resto da bacia. Nota-se assim que, quanto maior a sinuosidade do canal, maior deve ser o parâmetro de agrupamento dos segmentos. No entanto, o uso de um parâmetro de agrupamento muito elevado pode comprometer o desempenho da ferramenta em bacias de menor dimensão com sinuosidade elevada.

Em relação às áreas de confluência, as figuras $10 \mathrm{~A}$ e 10B apresentam, respectivamente, os resultados das aplicações das técnicas semiautomática e automática. Ao observar as confluências destacadas pelas setas, nota-se que a técnica semiautomática superestimou a dissecação horizontal, gerando classes de dissecação elevada em áreas de canal único. $\mathrm{O}$ produto gerado pela técnica automática apresentou um resultado mais coerente, conseguindo delimitar classes de dissecação horizontal mais altas apenas nas áreas de junção de vários canais. Esse fato explica a menor concordância da classe de menor dissecação (Classe 7, 49\% - Tabela 2) quando ambas as técnicas foram comparadas.

Observando ainda a figura 10 é possível notar algumas diferenças na classificação de áreas a montante das nascentes. Por conseguir medir com maior exatidão a distância entre o canal de drenagem e o limite da bacia, as classes de dissecação foram mais detalhadas e traçadas com maior precisão pela técnica digital automática. 


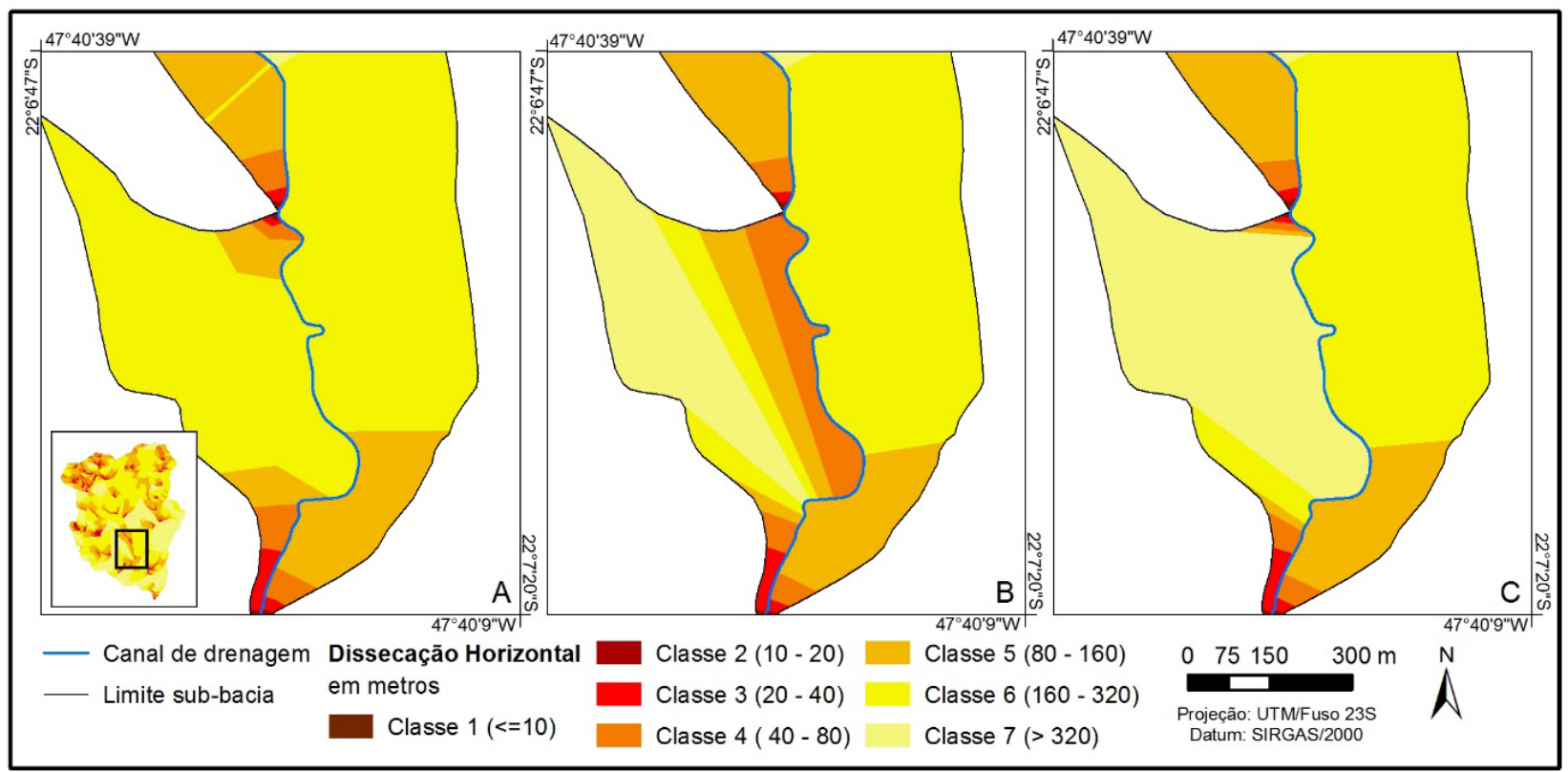

Figura 9 - Fragmento de mapas de dissecação horizontal com drenagem sinuosa A -Elaborado através da técnica semiautomática; $B$ - Elaborado através da técnica automática com parâmetro de agrupamento dos segmentos igual a 60; C - Elaborado através da técnica automática com parâmetro de agrupamento dos segmentos igual a 120.

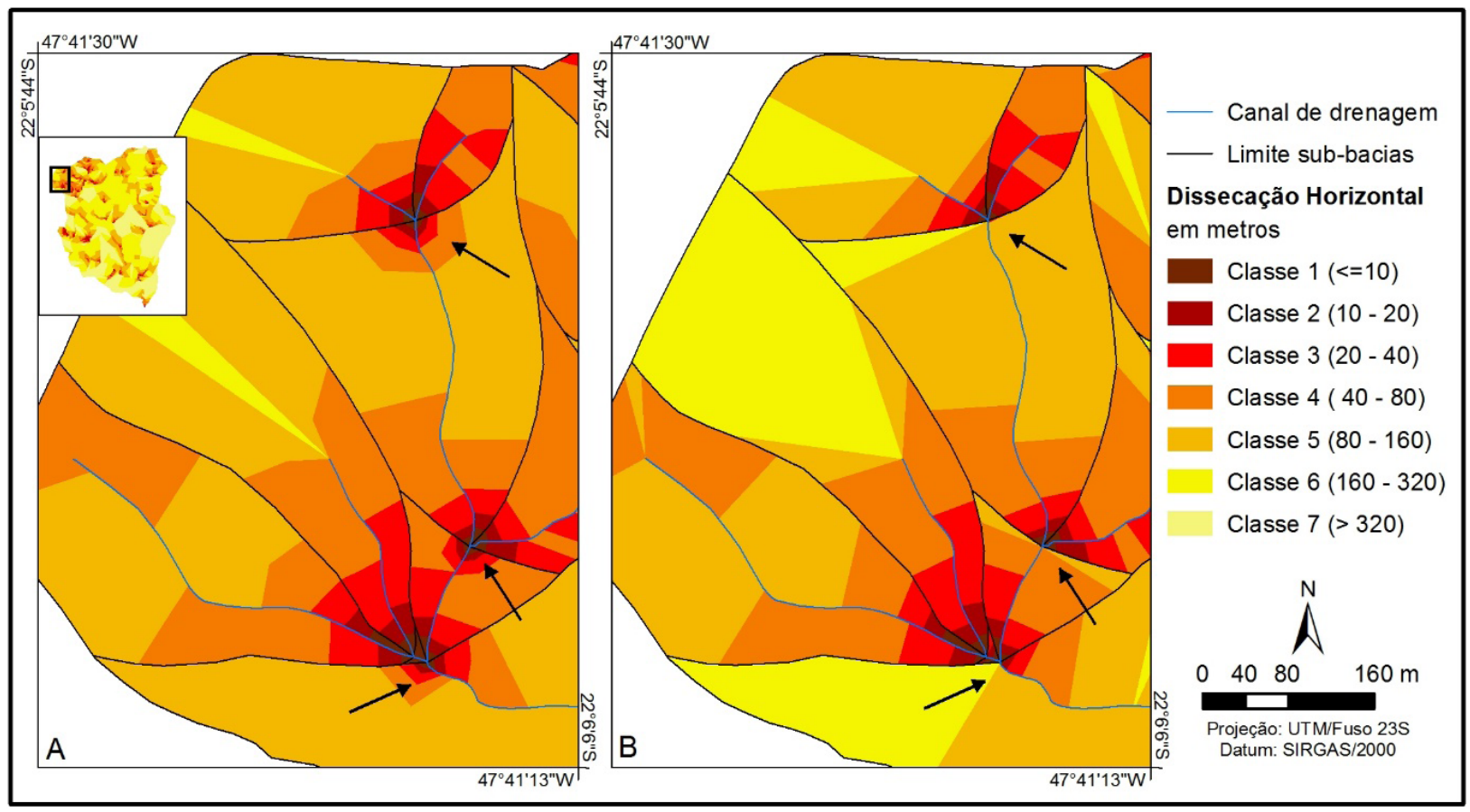

Figura 10 - Fragmento de mapas de dissecação horizontal com elevado número de confluências A - Elaborado através da técnica semiautomática; $B$ - Elaborado através da técnica automática.

\subsection{Tempo para execução dos mapeamentos}

O tempo foi contabilizado para ambas as técnicas no desenvolvimento do mapeamento em escala 1:10.000, tendo como área a bacia do Córrego do Cavalheiro, com $30,2 \mathrm{~km}$ de canais de drenagem e 73 sub-bacias.

A estimativa para o tempo de execução da técnica semiautomática proposta por Zacharias (2001) totalizou 160 horas de trabalho, que abrangem toda a criação de topologias, zonas buffer e polígonos de dissecação 
horizontal.

Já a técnica digital automática demandou 4 horas de trabalho para a preparação e ajustes da base de dados e, aproximadamente, 31 horas de processamento para a construção do mapa de dissecação. Nota-se que houve uma redução drástica do tempo total, mas principalmente no tempo de trabalho do pesquisador em si. É importante destacar que esse tempo de processamento foi atingido utilizando um computador com processador Intel Core I7 3.2GHz, com $12 \mathrm{~GB}$ de memória RAM e sistema Windows Server 2012.

\subsection{Replicabilidade}

A replicabilidade é um dos princípios básicos da ciência que fica comprometido em grande parte dos procedimentos manuais e semiautomáticos. $\mathrm{O}$ fator humano e a subjetividade inerente a sua análise podem limitar a reprodução dos resultados obtidos por outros pesquisadores. No caso da metodologia proposta por Spiridonov (1981) e adaptada por Mauro et al. (1991), o uso do ábaco, mesmo orientado pelos critérios de ângulo e menor distância, gera diferentes interpretações. Os limites das classes podem variar espacialmente, gerando distintos mapas de dissecação horizontal para uma mesma área. Na técnica semiautomática proposta por Zacharias (2001), o traçado do limite das classes a partir do vértice gerado pelas zonas buffer também implica em certa interpretação do ângulo desses limites, comprometendo a reprodução dos resultados.

No caso da técnica digital automática, a replicabilidade é intrínseca ao uso de algoritmos computacionais. Qualquer pesquisador que utilizar os mesmos dados de entrada obterá resultados iguais graças às regras pré-estabelecidas na ferramenta.

\subsection{Limitações da técnica automática}

Foram identificadas duas principais limitações na aplicação da técnica digital automática. A primeira trata-se de seu desempenho em trechos sinuosos dos canais de drenagem. Como já discutido no item 4.2, a ferramenta apresenta resultados pouco satisfatórios para canais muito sinuosos, pois o processamento dos dados está relacionado a uma variável que não pode ser determinada diretamente em função da escala, podendo variar para determinadas sub-bacias. Um modo de reduzir essa limitação seria processando individualmente as sub-bacias que apresentarem esse tipo de problema ou ainda empregando um parâmetro de agrupamento mais adequado.

A segunda limitação identificada refere-se aos trechos onde ocorre a ausência de determinadas classes de dissecação em função da forma da bacia e posição do canal de drenagem. Na figura 11 é possível observar dois pontos onde as classes não seguem uma sequência completa, pois a menor linha perpendicular à drenagem não pertencia a classe vizinha àquela do segmento anterior.

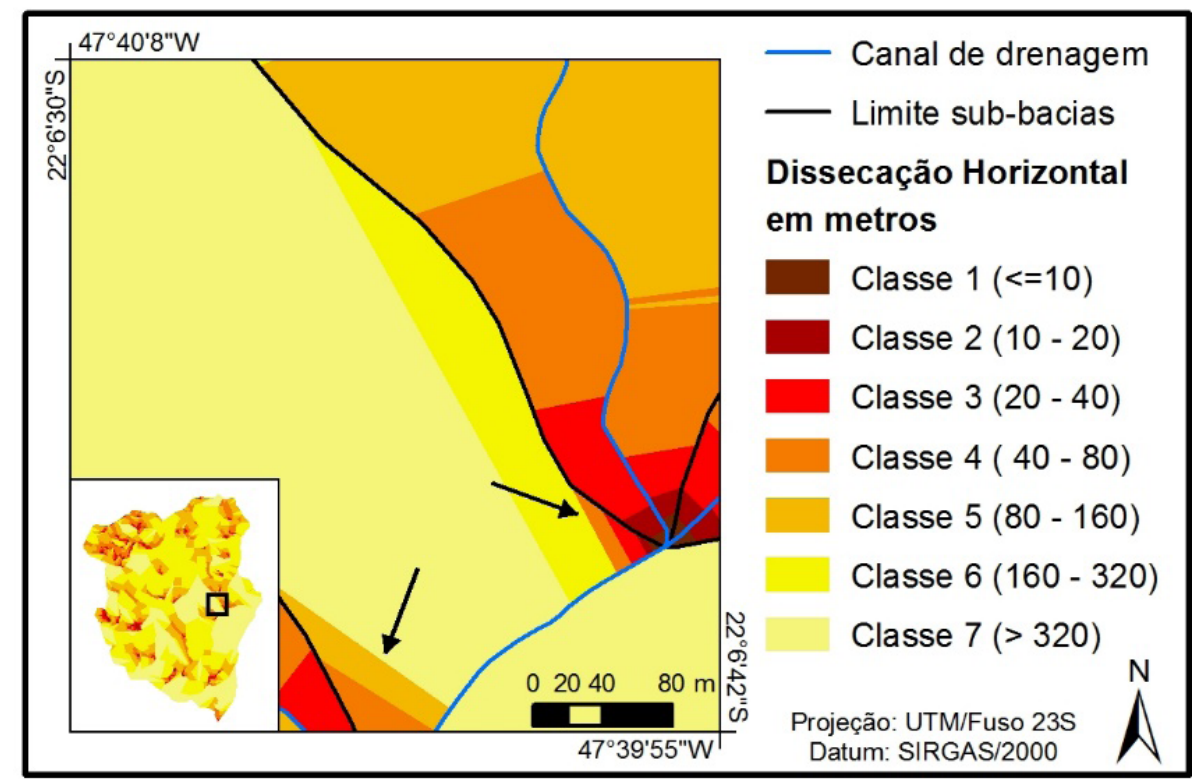

Figura 11 - Fragmento do mapa de dissecação horizontal elaborado através da técnica automática - Destaque para o problema de intervalos de classe. 


\section{Considerações Finais}

A dissecação horizontal constitui-se em um parâmetro morfométrico que utiliza como princípio o entendimento que a proximidade entre os cursos fluviais implica em maior potencialidade para a movimentação dos materiais constituintes do relevo ao considerar que o rio atua como um agente contínuo de erosão, deposição e transporte de sedimentos. Assim, o sistema de canais de drenagem é considerado como elemento que pode promover a desestabilização dos terrenos. A partir desse princípio, o mapeamento de tal parâmetro pode auxiliar na avaliação da suscetibilidade do relevo ao desencadeamento de processos morfogenéticos. Os resultados apontam que as classes mais fortes ocorrem em toda confluência, até mesmo dos pequenos cursos fluviais, e em nascentes muito próximas à linha de cumeada. Assim, recomenda-se sua elaboração quando se fazem necessários dados com grande nível de detalhe, a fim de identificar cada setor da área estudada que apresenta maior concentração de cursos fluviais e/ou nascentes em posicionamento que indicam possíveis futuras capturas.

Conforme evidenciado pelos resultados, a ferramenta elaborada neste trabalho se mostrou eficaz para o mapeamento da dissecação horizontal, viabilizando a aplicação da técnica em grandes áreas com ganho significativo de tempo. Por fim, evidencia-se o aumento da confiabilidade nos dados advindos deste documento cartográfico em razão da qualidade gráfica no resultado final e da maior precisão no seu processo de elaboração, especialmente pela possibilidade de realizar correções e testes dos dados introduzidos na plataforma do software.

\section{Agradecimentos}

Às bolsas de doutorado concedidas pelo Conselho Nacional de Desenvolvimento Científico e Tecnológico (CNPq), processos no 165930/2013-6 e no 165931/2013-2 e à Fundação de Amparo à Pesquisa do Estado de São Paulo (FAPESP), processo $n^{\circ}$ 2012/20513-0.

\section{Referências Bibliográficas}

AB'SABER, A. N. Regiões de circundesnudação pós-cretácea, no Planalto Brasileiro. Boletim Paulista de Geografia, São Paulo, n. 1, p. 3-21, 1949.

AB'SABER, A. N. Um conceito de geomorfologia a serviço das pesquisas sobre o quaternário. Geomorfologia, São Paulo, v. 18 , p. 1-23, 1969.

DIKAU, R.; BRABB, E. E.; MARK, R. K.; PIKE, R. J. Morphometric landform analysis of New Mexico. Zeitschrift für Geomorphologie Supplements, Berlim, v. 101, p. 109126, 1995.

EHSANI, A. H.; QUIEL, F. Geomorphometric feature analysis using morphometric parameterization and artificial neural networks. Geomorphology, Amsterdam, v. 99, n. 1-4, p. 1-12, 2008.

ESRI. ArcGIS 10.2.1 for Desktop. Redlands: ESRI, 2013. Cópia digital.

EVANS, I. S. General geomorphometry, derivatives of altitude and descriptive statistics. In: CHORLEY, R. J. (Ed.). Spatial analysis in geomorphology. New York: Harper and Row, 1972. p.17-90.

FACINCANI, E. M. Morfotectônica da depressão periférica paulista e cuesta basáltica: regiões de São Carlos, Rio Claro e Piracicaba, SP. 2000. 222f. Tese (Doutorado em Geologia Regional) - Instituto de Geociências e Ciências Exatas, Universidade Estadual Paulista, Rio Claro, 2000.

FLORENZANO, T. G. Cartografia. In: FLORENZANO, T. G (Org.). Geomorfologia: conceitos e tecnologias atuais. São Paulo: Oficina de textos, 2008. p. 105-128.

GHIMIRE, M. Multivariate morphological characteristics and classification of first-order basins in the Siwaliks, Nepal. Geomorphology, Amsterdam, v. 204, p. 192-207, 2014.

IBGE. Noções básicas de cartografia. Manuais Técnicos em Geociências. Rio de Janeiro: IBGE, 1999. 130p.

JASIEWICZ, J.; STEPINSKI, T. F. Geomorphons - a pattern recognition approach to classification and mapping of landforms. Geomorphology, Amsterdam, v. 182, p. 147-156, 2013.

MARK, D. M.; ARONSON, P. B. Scale-dependent fractal dimensions of topographic surfaces: an empirical investigation, with applications in geomorphology and computer mapping. Journal of the International Association for Mathematical Geology, New York, v. 16, n. 7, p. 671-683, 1984.

MAURO, C. A.; RUSSO, I. L.; BOVO, R.; TELES, A. P. S. S.; CARVAlHO, M. B., S.; PICARELli, A.; MELO, A. M. M. Contribuição ao planejamento ambiental de Cosmópolis - SP - BR. In: ENCUENTRO DE GEÓGRAFOS DE AMÉRICA LATINA, 3., 1991, Toluca. Resumos...Toluca: Universidad Autónoma del Estado de México, 1991. p. 391-419. 
MELO, M. S. A Formação Rio Claro e depósitos associados: sedimentação neocenozóica na depressão periférica paulista. 1995. 144 f. Tese (Doutorado em Geociências) - Instituto de Geociências, Universidade de São Paulo, São Paulo, 1995.

MINÁR, J.; EVANS, I. S. Elementary forms for land surface segmentation: the theoretical basis of terrain analysis and geomorphological mapping. Geomorphology, Amsterdam, v. 95, n. 3-4, p. 236-259, 2008.

MORSE, S. P. A Mathematical model for the analysis of contour-line data. Journal of the Association for Computing Machinery, New York, v. 15, n. 2, p. 205-220, 1968.

PENTEADO, M. M. Geomorfologia do setor centro-ocidental da Depressão Periférica Paulista. 1968. 86f. Tese (Doutorado em Geografia Física) - Faculdade de Filosofia, Ciências e Letras de Rio Claro, Rio Claro, 1968.

PENTEADO, M. M. Fundamentos de geomorfologia. Rio de Janeiro: IBGE, 1974. 141p.

PEUCKER, T. K.; DOUGLAS, D. H. Detection of surfacespecific points by local parallel processing of discrete terrain elevation data. Computer graphics and image processing, New York, v. 4, n. 4, p. 375-387, 1975.

SÃO PAULO (Estado). Secretaria de Agricultura e Abastecimento. Coordenadoria da Pesquisa de Recursos Naturais. Folha geológica de Corumbataí (Folha SF-23-Y-A-I-2): Formações Geológicas de Superfície. São Paulo: Instituto Geológico, 1984. Escala 1:50.000.

SILVA, G. da; PINTO, A. L. Aprimoramento de metodologias e técnicas cartográficas de mapeamento morfológico - estudo de caso: a bacia do córrego Fundo, Aquidauana, MS. In: Simpósio De Geotecnologias No Pantanal, 1., 2006, Campo Grande. Anais... Campinas: Embrapa Informática Agropecuária; São José dos Campos: INPE, 2006, p. 949-958.

SPIRIDONOV, A.I. Princípios de la metodologia de las investigaciones de campo y el mapeo geomorfológico. Havana: Universidad de la Habana, 1981. Vol. 3, 650p.

STEINKE, V. A.; SANO, E. E. Semi-automatic identification, GIS-based morphometry of geomorphic features of Federal District of Brazil. Revista Brasileira de Geomorfologia, São Paulo, v. 12, n. 1, p. 3-9, 2011.

TRICART, J. Principes et méthodes de la géomorphologie. Paris: Masson, 1965. 496p.

ZACHARIAS, A. A. Metodologias convencionais e digitais para a elaboração de cartas morfométricas do relevo. 2001. 166f. Dissertação (Mestrado em Geociências e Meio Ambiente) - Instituto de Geociências e Ciências Exatas, Universidade Estadual Paulista, Rio Claro, 2001. 